\title{
Investigation of best digital technological practices in millennial classroom innovation: critical review study
}

\author{
Sudarmo \\ Sekolah Tinggi Ilmu Ekonomi Balikpapan, Indonesia \\ Email: sudarmo@stiebalikpapan.ac.id \\ Rasmita \\ Universitas Putra Indonesia YPTK Padang, Indonesia \\ Corresponding author email: rasmita@upiyptk.ac.id \\ Erwinsyah Satria \\ Universitas Bung Hatta, Indonesia \\ Email: erwinsyah.satria@bunghatta.ac.id
}

\begin{abstract}
This paper aims to critically review best technology practices for native digital students in Indonesia. The success of learning using technology today cannot be separated from educators' ability to choose technology practice models from various learning sources. To present practices used for the digital generation, we have looked at data from dozens of scientific findings that examine digital best practices, particularly those that improve learning outcomes. After the data has been collected, we continue the critical review process to discuss the phenomenon and its attributes. Searching for data, analyzing, and summarizing data to answer the research questions was carried out with validity and reliability. We rely on online data searches. The result uses devices, teleconferencing, smart boards, reflective web journals, cloud servers, $3 D$ printing, learning and practicing, maintaining flexibility and persistence, promoting collaboration, feedback, and research culture. Thus, these results will serve as essential reminder inputs for educators and researchers, curriculum innovation.

Keywords critical review study, digital class, digital native, technology practice.
\end{abstract}

\section{Introduction}

The planet is busy with many technological advancements without understanding it (Koehler \& Mishra, 2009). Many countries are competing to create technologies to make it simpler for all aspects of human life, including the education industry, from elementary school to postgraduate education. We have to thanks to technical assistance, nowadays, teaching and learning activities not only have to be carried out in schools but can also be carried out even though they are quite far apart. However, even so, this also needs adjustments from several parties. Because not only does it have a positive impact, technology will backfire if it is not used wisely and appropriately. Respond to this phenomenon; this educational paper will review various data sources and discuss the best practical technology for a class of millennial or native digital students with the themes mentioned above.

Discussions about best practice media technology and its proper use in education are critical in implementing education today, especially in classrooms McClure \& McAndrews (2016) said classrooms for the millennial generation or digital natives. Therefore, the learning atmosphere must be integrated natively with various digital tools and technological innovations because they are a generation born after this technology that was present around the 2000s. Moreover, various forms of education challenges in Indonesia, especially the priority of selecting educational technology to improve high learning outcomes, need more attention from various parties. Many people have expressed various concerns about the presence of technology in Indonesia. Some others believe that there are many uses, such as educators and educational institutions, to manage technology and processes more efficiently, 
focusing not only on learning outcomes that are intellectual material but also on shaping children's character, sharing interests, and fostering conceptual and thinking critically with interactive classes.

The reason for this study is very appropriate to be carried out considering that until today the world is still haunted by the issue of COVID-19 with all government policies responding; of course, not a few of these regulations have hindered the education process of the younger generation where they are restricted from moving because they are afraid of contracting the virus (Putra et al., 2020; Aslan et al., 2020). Respond to this issue, the education continues, and health protocols are not violated; education now does not apply to the old system where education actors must come to schools or lecture halls, which are very risky in periods that are still pandemic warnings for teaching and learning activities. So with technology solutions and practical best, it is expected that education is limited in the classroom but reaches far and wide. In other words, education should not be seen as merely a humanassisted facial appearance by keeping away the convenience of technological facilities.

Although technology today in many developed countries has successfully innovated their education with the latest technology, this study does not discuss the advantages of digital innovation in the classrooms of digital native country students, so they forget the traditional aspects and wisdom of the world of education that involves teachers who are own superior technology. This study does not entirely dualize human abilities and the active role of parents and the wider community. Instead, the models and solutions that we will discuss are technology best practice programs assisted by teachers. In essence, no technology can produce superior student learning output without a teacher's presence with the function of facilitator and motivator above the ability of technology Tondeur et al. (2012), Carpenter \& Pease (2013) said that the preparation of before the teachers for the introduction of online education as a synthesis of qualitative facts is urgent throughout modern day education.

This is also confirmed by Hanson-Smith (2016) who said that teachers and technology have two fundamental elements that must be brought together to make education successful in any era (Ramnarain \& Hlatswayo, 2018; Assunção Flores \& Gago, 2020; Leithwood, 2003; Lee \& Lehman, 2016; Carayannis \& Von Zedtwitz, 2005). They added that teachers are education experts who are also a researcher on educational issues in all times. They must play an active role that is always supported by parents and schools that will not be replaced, especially in shaping the character of millennial generation students who are often claimed by teachers to be defeated by their abilities technology. Therefore the role of technology in the school environment is intended as a media tool and means to assist the learning process, open access, and improve the quality of learning as an example of the application of technology to advance student achievement in some developed countries.

Levani et al. (2020) revealed that the Indonesian people are a tremendous resource in utilizing the internet. Likewise, the ability of the Indonesian people is quite useful in using digital technology. However, it is unfortunate that its use is still fun and entertaining. Seeing this phenomenon, it is better if schools as the production of educators can take advantage of digital technology to facilitate learning to no longer traditional. Starting from a motivational sentence, no matter how sophisticated, technology will never replace the teacher's role. However, teachers who do not want to learn technology are sure to be replaced. Then this can be a place to start. Teachers can pour creative ideas to develop digital technology adapted for learning and education for the young generation of native digital millennials. Educational applications and social media used by the community are undoubtedly familiar in our daily lives.

By use of existing digital technology applications, such as studying social media platforms, cannot be generalized because not all teachers can understand its usefulness. This is because every teacher has various skills. Likewise, every learning has characteristics, distinguishing indicators that cause specific methods and media cannot be generalized and can be used directly without experts or the data from the study results beforehand, both its usefulness and efficiency. In this case, Ross et al. (2010) findings are also very relevant to consider the material being taught, the characteristics of students, conditions in the field, and educators' competence as indicators or a basis for analyzing the learning needs of digital technology. For this reason, teachers must be accompanied by researchers, or at least there is data on findings that a digital application can be applied in the classroom. All of this needs to be prepared by making a learning plan based on digital technology innovation so that it becomes one of the best practices in the class of students who live and learn in the millennial era. Such learning plans should be tailored to the school's needs and abilities because there is no generic media for various learning situations and conditions, let alone with Indonesia's normal practical conditions.

With digital technology that can renovate the world of teaching, it is hoped that it will minimize gaps between sectors and groups. Students now include the millennial generation born between 2000-2010 generations who are the majority of computers, devices, and the internet today. They are also proficient in developing various information systems according to the needs of the increasingly challenging times. For this reason, there are many benefits provided by digital media in an educational context, including increasing the involvement of students in learning, 
helping students work through difficult concepts, helping to promote critical awareness, helping promote equality, and many more benefits provided.

If studied in-depth, that learning resources and learning media have various kinds of diversity. Teachers need to have the skills to identify various types of best teaching practice models by involving multimedia technology to take advantage of existing learning resources, both those that have been designed and those who need to use them just what has been made. The difference is that learning resources by design are learning resources that are deliberately designed and made for learning purposes, for example, textbooks or interactive multimedia CDs. Meanwhile, by utilization, learning sources are existing learning resources that can be arranged to become sources for learning, for example, sources or markets that are a place to look for certain learning information (Merschbrock \& Munkvold, 2015; Royle \& Laing, 2014).

Suppose serious educators pay attention to the current digital technology trend in education, affecting student learning. According to Garland (2009) various media can be adopted in education, including Google glass reality/mixed reality, redeveloped spaces for learning artificial intelligence, personalization of learning, and gamification. The teaching profession should have the skills to use technology to improve learning processes and outcomes. As for the types of learning media with digital technology that can be utilized, among others: interactive multimedia, digital video, and animation, podcasts, augmented reality, virtual reality, and game-based learning and gamification.

Furthermore, the benefits of using digital technology media in education can introduce classrooms to opportunities and resources that students may not have access to. Examples of digital technology resources that can be used to engage and educate in the classroom are videos, educational games, and virtual simulations. Likewise, the use of technology or media in learning has its challenges. For example, limited budget costs and the environment and its aspects are a subsystem in learning that also affects the successful use of technology in learning. However, despite these challenges, integrating digital technology media into learning is a necessity today. Because preparing students to be ready for their future life, they must start immediately from studying at school. It is sometimes difficult to design learning activities that fit the real world. Thus, digital technology media are needed to present the virtual world to replace the real world and all its problems in the classroom.

Finally, the conclusion is that integration in digital technology learning media is good, namely when students use technology every day but have access to various tools suitable for learning tasks and provide opportunities for students to build a deeper understanding of content. Technology integration also depends on the available types of technology, and the number of access students has to technology. The ability to respond to change is a crucial prerequisite for implementing the right technologies. This is an evolving process that involves continuous learning for all parties, especially as the spearhead of Indonesian education for teachers.

Progress in the Industrial Revolution 4.0 is a change in business and technology and various other aspects relevant to technological developments, including education and research. Gill (2018) said that new developments and future computing innovations are a vision for information technology in an intelligent environment. Related areas, including technical advancements, such as artificial intelligence, cloud, and big data analytics. Gill also added significant prerequisites are the automation of robotic processes, Blockchain, Internet of Things, and data science, Edge Computing, Quantum Computing, Virtual Reality and Augmented Reality. In order to become a significant player in the 4.0 technological revolution, it must be mastered now. Therefore, the way to do this is through educational innovation-based involving digital in all life and work sectors.

Technology and other universities According to Ferraz \& Fernandez (2020) the industry trend with an enormous economic value today is an industry with added-value commodities in the form of technology services. This can be seen from the number of business platforms that have developed in the community. Changes and dynamics of public demand that adapt to technological developments require business people to think outside the box to continue to exist in a highly competitive market. Innovation plays a more dominant role in accommodating the continuity of the business world cycle. Companies must offer superior products that have a faster cycle turnaround because of the need for an improvement process every time. To get there, the efforts to transfer education in technology and innovation are imperative.

They address future challenges: Artificial Intelligence, Big Data, and Cloud computing in higher education. The same thing was conveyed by Arduengo \& Sentis (2020) that the relationship between robots and economic predictions in the next 20 years, approximately $50 \%$ of jobs in modern countries such as the US and China, Britain, Germany, and Japan will be replaced by robots/automation. However, the majority of millennial generations think that technology can create jobs rather than eliminate them. This implies that the millennial generation considers that existing technological developments are an opportunity rather than a threat. Indonesia's economic future lies in bonuses to natural wealth. So this is where there are opportunities for natural wealth and challenges to enrich the 
opportunities for empowering Indonesia's human resources. So the most appropriate solution is technological innovation and revolution in education.

The most appropriate solution for Indonesia's size is now possible by presenting technological innovation studies and collaboration in education. In integrating technology into artificial intelligence and cloud learning, the results of a collaboration between universities and applied educational institutions are hoped. It can be produced able to accelerate research and development of automation and cloud and other intersecting fields so that they are implemented in a real sense so that researchers can work together to produce new findings on an understanding of big data, Artificial intelligence, data centers, and the Internet - Procedures. On that basis, academics must be able to collaborate with industry practitioners in research centers. We academics and technology experts are slowly looking forward to supporting developing students with a strategic study of the application of emerging technological advances by exploring best practice learning in Millennial Generation Schools.

\section{Materials and Methods}

As explained in the introduction, this study intends to find out the best digital technology practice models in educational activism towards learning innovation for students' millennial generation. We chose the method of reviewing data from scientific publications that discuss learning innovation technology in the era of revolution 4.0. The first step we take is to read the introduction from various related literary sources. We target journal publications between 2005 and 2020. After the data is collected, then a critical analysis is carried out using a phenomenological approach. Critical data analysis begins with understanding the research question. It then identifies themes or keywords, assesses the data we review, and interprets all data from findings on previous research topics from international publications via Google Scholar guidelines; ERIC is the premium online publication and writing guide for Grammarly applications. Hence, based on the quality and consistency of results, we are confident that the review data has met the study's demand. Under the guidance of Noble \& Smith (2015) we carry out this report, namely a study of validity and reliability issues in qualitative science.

\section{Results and Discussions}

\section{Best digitalization in education practices}

One of the answers to the best practical problems of innovation technology for improving learning outcomes to create millennials comes from Indahingwati et al. (2019) who question how digital technology encourages the millennial generation's behavior in Indonesia. Their study describes, predicts, and reflects on 300 companies that can use digital technology to change millennials' paradigm and perception and future generations in behaving as a generation of technology connoisseurs. A summary of learning decision-making trends in influencing millennial students' culture and the young generation is also presented in this report. In conclusion, the society of this generation and future generations are influenced and transformed by emerging media. Maksimović (2018) also expressed a similar issue, who said that the Internet of Things (IoT) reveals the ability to change various aspects of our daily lives dramatically. As one of the most critical issues and investments in a new world, education has not remained resistant to novel technology developments. In addition to technologies, an improved IoT-supported educational ecosystem involves a greater degree of cooperation between organizations, staff members, and researchers.

Hartong (2019) proves that the way to transform education quality control systems and state market demands in Germany and the United States is to link school data collection and digitization to the global education market. In this segment, he discussed the increasing data transfer and digitalization of education. He was focused on the transformation of state-level school administration monitoring programs. This transition is an essential but underexplored part of the demand for education technology (EdTech). For state, corporation, private, and philanthropic actors, it has modified and added new positions. The next result from Trust \& Maloy (2017) explored the effect on student learning of 3D projects, where students were able to acquire those skills when working on a 3D printing project. These results are closely parallel to the skills defined by teachers and the list of skills that millennials can learn in the 21 st century, indicating that teaching through $3 \mathrm{D}$ projects is a positive solution to training students for the new age to live and work.

In joint research with higher education best practice projects, the results were that Altınay (2017) successfully analyzed and completed online peer learning and evaluation. The effect of online peer learning on skill acquisition was also successfully explored in a review with its recent finding that online interactive peer learning processes in 
universities promote objective thinking and student self-assessment. Thus, in an environment of co-learning or online collaboration to re-create original digital learner expertise in the 21 st century, this research recognizes the importance of student satisfaction by best practicing collaborative learning in an online-based way. Similarly, Bayne \& Ross (2011) have succeeded in assessing the coding experience as a playground with the KIBO robotics kit in line with the constructive technological development paradigm. Their findings confirm that modern literacy can be learned from an early age at three years of age in a method used to encourage students to be motivated to start directly engaging in coding skills as part of learning and playing in the area of technology development as part of practical best learning in the digital age.

The practice of reviews from a peer review perspective in higher education has been rethought by Nicol et al. (2014). Students have already measured their work in their research and generated their input. This focus change has significant consequences for the way teachers coordinate appraisal and facilitate learning. The study underlying each theory of feedback is discussed, and some examples are briefly defined of easy-to-implement feedback strategies. Although one of the best practices of today's best education was examined by Anderson et al. (2016) this is how to give negative Millennial reviews to be successful. Since, according to Anderson, the millennial generation needs to get consistent and sustainable negative reviews. The Millennial generation would also treat the reviews as beneficial for them now or in the future. Think of a boss who needs to be firm enough to make sure the worker acknowledges his issues but is receptive to the fact that this criticism is challenging for many Millennials to consider.

\section{Millennial Classroom Innovation}

Husni (2020), Abdi (2014) discovered how evidence-based research in university experimental learning impacts religious learning patterns. This work aims to explore the relevance of the paradigm of investigation learning so that students are more involved in the research process. There was greater school behavior for students who learned to use the inquiry learning model than for the student population who did not use it. The implementation of projectbased learning models and audio-visual media by Saputra et al. (2018) will improve student activity. Saputra's findings were to determine whether the use of project-based learning facilitated by audio-visual media would increase student activity. The results of observations, surveys, ionic papers, and questionnaires were collected. After the analysis revealed that Audio-Visual Media helped introduce PBL in Economics, the results showed an increase in learning practices in their classroom lessons.

McCabe \& Meuter (2011) said that the perception of technology in the classroom by a student then questions if it improves the seven good practice standards of undergraduate education? There is a lack of study investigating the relationship between classroom technologies and student learning. This research is exploring the use of faculty of classroom-based course management tools. Although students enjoy using many of the tools of course management, the authors find that the devices are not very effective in maximizing the learning environment.

Karakas et al. (2015) discusses management learning at millennial architecture students' life steps with an interactive, innovative, and shared environment. The management learning at the pace of life is presented in this paper as a metaphor for inspiring millennials. When it comes to leadership learning, millennials can run into three big problems: lack of focus, lack of commitment, and outreach. Solve it; this study highlights the advantages of reflective, innovative, and interactive spaces online so that millennial students are more motivated to organize their learning innovatively and independently. Also, to complete this millennial learning innovation (Manning et al. 2017). Examined the use of Twitter and Socrative applications for sports management schools. New perspectives and constructive learning environments can be presented through the convergence of technology and creativity. Socrates has the power to arouse curiosity and critical thinking skills among students.

A series of existing literature reviews to critically examine the best technology practices for native digital students in Indonesia is interesting. So in this context, we need to discuss some of our findings from this best practical learning study because the focus on acquiring expertise and knowledge by modern millennial students is more on constructing knowledge together with others. Effective learners have acquired new knowledge from the individual process of working with the social environment necessary to be effective learners. So the solutions provided by technology have proven to be effective and productive.

For example, when teachers adopt learning activities with the adoption of digital technology, this effort will make the classroom engaging and fun so that students will be more willing to study for a long time by participating and willing to take risks from the negative side of technology themselves. It is a scientific fact that students are having fun while learning will help them get and retain information better because going through fun and impressing is not severe. Furthermore, technology in learning allows millennial students to adjust to learning that is the times' demands, namely learning with fast speed and succession. With technological innovation, slow students can also get 
extra time testing, repeat more times to practice, and do assignments until they understand and complete. Meanwhile, fast students can complete their studies faster with the support of technology. This technology can also make it easier for teachers to help less familiar students with more support at the individual level (Zhao \& Bryant, 2006; All et al., 2016; Straker et al., 2018).

Here are some of the advantages of digital technology when adopted in the classroom as the best practices study group for the millennial generation: Technology allows students to access knowledge and information from the World Wide Web easily, abbreviated www. Once there is a web, students can access knowledge like they have made this big world a free village. With best practices in the classroom, millennials can save time, such as student mobility, to get extensive information. A series of findings on the effectiveness and usefulness of digital technology for millennial students have proven that digital media tools are more communicative and innovative, making students more motivated and fun in class. Other findings, such as digital and technological innovations, can make it possible to learn more economically than traditional methods. The next most crucial finding is that technological innovation now has a variety of models and uses. For example, a banking management system for lessons and better documentation, and an up-to-date learning way is also better.

\section{Conclusion}

Based on the discussion of this study's findings to identify the best practical digital technology in millennial generation schools in Indonesia. With the various findings and existing supporting data, we can conclude that the results of the analysis of many international publications sources, among others, show that using technological tools is proven to be able to activate students to continue learning. When all schools are closed due to state policies, online-based technology will continue to be encouraged, such as teleconferencing and others. Likewise, the use of smart boards is beautiful to millennial students. When students come home, the reflective web journal is very interesting for how to complete the assignment. Especially for students with good literacy, cloud servers, 3D printing, non-stop learning, and practice, keeping flexible are useful. They need to be introduced more deeply, namely literacy and perseverance in technology. Likewise, efforts to promote cooperation and collaboration are exciting. No less important, for example, actively providing feedback for students and offering valuable input and research-based learning. Thus, these findings will be useful and become new findings, useful reminder input for teachers, education researchers, and curriculum innovation to achieve national education goals.

\section{Acknowledgments}

The authors would like to thank colleagues, academic supervisors, time editors, and the department for funding this study from start to finish. We feel that without the support of all this, we could not have done our paper with the topic "Investigation of Best Digital Technological Practices in Millennial Classroom Innovation: Critical Review Study."

\section{References}

Abdi, A. (2014). The Effect of Inquiry-Based Learning Method on Students' Academic Achievement in Science Course. Universal Journal of Educational Research, 2(1), 37-41.

All, A., Castellar, E. P. N., \& Van Looy, J. (2016). Assessing the effectiveness of digital game-based learning: Best practices. Computers \& Education, 92, 90-103. https://doi.org/10.1016/j.compedu.2015.10.007

Altınay, Z. (2017). Evaluating peer learning and assessment in online collaborative learning environments. Behaviour \& Information Technology, 36(3), 312-320.

Anderson, E., Buchko, A. A., \& Buchko, K. J. (2016). Giving negative feedback to Millennials. Management Research Review.

Arduengo, M., \& Sentis, L. (2020). The Robot Economy: Here It Comes. International Journal of Social Robotics, $1-11$.

Aslan, A., Silvia, S., Nugroho, B. S., Ramli, M., \& Rusiadi, R. (2020). Teacher's leadership teaching strategy supporting student learning during the covid-19 disruption. Nidhomul Haq: Jurnal Manajemen Pendidikan Islam, 5(3), 321-333. https://doi.org/10.31538/ndh.v5i3.984

Assunção Flores, M., \& Gago, M. (2020). Teacher education in times of COVID-19 pandemic in Portugal: National, institutional and pedagogical responses. Journal of Education for Teaching, 1-10.

Bayne, S., \& Ross, J. (2011). 'Digital native'and 'digital immigrant'discourses: A critique. In Digital difference (pp. 159-169). Brill Sense. 
Carayannis, E. G., \& Von Zedtwitz, M. (2005). Architecting gloCal (global-local), real-virtual incubator networks (G-RVINs) as catalysts and accelerators of entrepreneurship in transitioning and developing economies: lessons learned and best practices from current development and business incubation practices. Technovation, 25(2), 95110. https://doi.org/10.1016/S0166-4972(03)00072-5

Carpenter, J. P., \& Pease, J. S. (2013). Preparing students to take responsibility for learning: The role of noncurricular learning strategies. Journal of Curriculum and Instruction, 7(2), 38-55.

Ferraz, E., \& Fernandez, G. (2020). Achmad Zaky: Founder and CEO, Bukalapak. In Asian Founders at Work (pp. 105-113). Springer.

Garland, V. E. (2009). Emerging technology trends and ethical practices for the school principal. Journal of Educational Technology Systems, 38(1), 39-50.

Gill, D. S. N. S. (2018). Emerging trends and future computing technologies: A vision for smart environment. International Journal of Advanced Research in Computer Science, 9(2).

Hanson-Smith, E. (2016). Teacher education and technology. The Routledge Handbook of Language Learning and Technology, 210-222.

Hartong, S. (2019). The transformation of state monitoring systems in Germany and the US: Relating the datafication and digitalization of education to the Global Education Industry. In Researching the global education industry (pp. 157-180). Springer.

Husni, H. (2020). The Effect of Inquiry-based Learning on Religious Subjects Learning Activities: An Experimental Study in High Schools. Jurnal Penelitian Pendidikan Islam, 8(1), 43-54.

Indahingwati, A., Launtu, A., Tamsah, H., Firman, A., Putra, A. H. P. K., \& Aswari, A. (2019). How Digital Technology Driven Millennial Consumer Behaviour in Indonesia. The Journal of Distribution Science, 17(8), 25-34.

Karakas, F., Manisaligil, A., \& Sarigollu, E. (2015). Management learning at the speed of life: Designing reflective, creative, and collaborative spaces for millenials. The International Journal of Management Education, 13(3), 237-248.

Koehler, M., \& Mishra, P. (2009). What is technological pedagogical content knowledge (TPACK)? Contemporary Issues in Technology and Teacher Education, 9(1), 60-70.

Lee, C. I., \& Lehman, C. D. (2016). Digital breast tomosynthesis and the challenges of implementing an emerging breast cancer screening technology into clinical practice. Journal of the American College of Radiology, 13(11), R61-R66. https://doi.org/10.1016/j.jacr.2016.09.029

Leithwood, K. (2003). Teacher leadership: Its nature, development, and impact on schools and students. Leadership in Education, 103-117.

LEVANI, Y., HAKAM, M. T., \& UTAMA, M. R. (2020). Potensi Adiksi Penggunaan Internet pada Remaja Indonesia di Periode Awal Pandemi Covid 19. Hang Tuah Medical Journal, 17(2), 102-115.

Maksimović, M. (2018). IOT concept application in educational sector using collaboration. Facta Universitatis, Series: Teaching, Learning and Teacher Education, 1(2), 137-150.

Manning, R. D., Keiper, M. C., \& Jenny, S. E. (2017). Pedagogical innovations for the millennial sport management student: Socrative and Twitter. Sport Management Education Journal, 11(1), 45-54.

McCabe, D. B., \& Meuter, M. L. (2011). A student view of technology in the classroom: Does it enhance the seven principles of good practice in undergraduate education? Journal of Marketing Education, 33(2), 149-159.

McClure, C., \& McAndrews, L. E. (2016). Going native to reach the digital natives: New technologies for the classroom. International Textile and Apparel Association Annual Conference Proceedings, 73(1).

Merschbrock, C., \& Munkvold, B. E. (2015). Effective digital collaboration in the construction industry-A case study of BIM deployment in a hospital construction project. Computers in Industry, 73, 1-7. https://doi.org/10.1016/j.compind.2015.07.003

Nicol, D., Thomson, A., \& Breslin, C. (2014). Rethinking feedback practices in higher education: A peer review perspective. Assessment \& Evaluation in Higher Education, 39(1), 102-122.

Noble, H., \& Smith, J. (2015). Issues of validity and reliability in qualitative research. Evidence-Based Nursing, 18(2), 34-35. https://doi.org/10.1136/eb-2015-102054

Putra, P., Liriwati, F. Y., Tahrim, T., Syafrudin, S., \& Aslan, A. (2020). The Students Learning from Home Experiences during Covid-19 School Closures Policy In Indonesia. Jurnal Iqra': Kajian Ilmu Pendidikan, 5(2), 30-42. https://doi.org/10.25217/ji.v5i2.1019

Ramnarain, U., \& Hlatswayo, M. (2018). Teacher beliefs and attitudes about inquiry-based learning in a rural school district in South Africa. South African Journal of Education, 38(1). 
Ross, S. M., Morrison, G. R., \& Lowther, D. L. (2010). Educational technology research past and present: Balancing rigor and relevance to impact school learning. Contemporary Educational Technology, 1(1), 17-35.

Royle, J., \& Laing, A. (2014). The digital marketing skills gap: Developing a Digital Marketer Model for the communication industries. International Journal of Information Management, 34(2), 65-73. https://doi.org/10.1016/j.ijinfomgt.2013.11.008

Saputra, I. G. N. H., Joyoatmojo, S., \& Harini, H. (2018). The implementation of project-based learning model and audio media Visual can increase students' activities. International Journal of Multicultural and Multireligious Understanding, 5(4), 166-174.

Straker, L., Zabatiero, J., Danby, S., Thorpe, K., \& Edwards, S. (2018). Conflicting guidelines on young Children's screen time and use of digital technology create policy and practice dilemmas. The Journal of pediatrics, 202, 300-303. Ertmer, P. A., Ottenbreit-Leftwich, A. T., Sadik, O., Sendurur, E., \& Sendurur, P. (2012). Teacher beliefs and technology integration practices: A critical relationship. Computers \& education, 59(2), 423-435. https://doi.org/10.1016/j.compedu.2012.02.001

Tondeur, J., Van Braak, J., Sang, G., Voogt, J., Fisser, P., \& Ottenbreit-Leftwich, A. (2012). Preparing pre-service teachers to integrate technology in education: A synthesis of qualitative evidence. Computers \& Education, 59(1), 134-144.

Trust, T., \& Maloy, R. W. (2017). Why 3D print? The 21st-century skills students develop while engaging in 3D printing projects. Computers in the Schools, 34(4), 253-266.

Zhao, Y., \& Bryant, F. L. (2006). Can teacher technology integration training alone lead to high levels of technology integration? A qualitative look at teachers' technology integration after state mandated technology training. Electronic Journal for the Integration of Technology in Education, 5(1), 53-62. 